\title{
Mineralogical, textural and liberation studies of tungsten ore deposits of Chitral, Khyber Pakhtoon Khwa Province, Pakistan
}

\author{
Rashid Mehmood ${ }^{1, *}$, Muhammad Arif Bhatti ${ }^{1}$, Kashif Butt ${ }^{2}$, Kamarn Raza Kazmi ${ }^{1}$ and Adnan Akram ${ }^{1}$ \\ ${ }^{1}$ Mineral Processing Research Centre, PCSIR Laboratories Complex, Lahore-54600, Pakistan \\ ${ }^{2}$ College of Earth and Environmental Sciences, University of the Punjab, Lahore-54590, Pakistan \\ *Corresponding author: rashidgeologist@hotmail.com
}

\begin{abstract}
An investigation was undertaken on tungsten ore deposits of Chitral area, Khyber Pakhtoon Khawa Province, Pakistan for its evaluation and subsequently selection of a suitable process for its beneficiation. The ore deposit was evaluated by microscopy, petrography, X-ray diffractometry and chemical analysis. The principal mineral constituents present in the ore were identified. The textural characteristics such as crystal size, shape and mutual arrangement of the component minerals in the ore body were investigated. The degree of liberation of valuable mineral was studied by grain mounts. Mineralogy, texture and liberation studies reveal that this ore is amenable to beneficiation by froth flotation technique.
\end{abstract}

Key words: Tungsten ore, mineralogy, texture, liberation, scheelite, beneficiation, Chitral

Received: January 15, 2014

Revision accepted: April 20, 2014

\section{INTRODUCTION}

Tungsten is a steel-gray metal with many distinct properties and diverse applications. It is relatively a rare metal, being $0.00015 \%$ of the earth's crust (Foster, 1988). It occurs in nature in more than twenty minerals but the economically important minerals are scheelite $\mathrm{CaWO}_{4}$ and wolframite (Fe, Mn) $\mathrm{WO}_{4}$ series (Blackburn, 1988). Tungsten deposits occur where mineralization has taken place at high temperatures and pressures. The deposits containing wolframite are typically of igneous origin and wolframite occurs in quartz veins or segregated in pegmatites. Scheelite is normally found in skarn deposits formed through contact metamorphism by the replacement of limestone bed, in high-temperature hydrothermal veins and greisens; less commonly in granitic pegmatites (Zulfiqar and Hariri, 2006; Chowdhury, 2007; Tornos et al., 2008).

For extraction of metal from an ore deposit it is important to select the optimum economic process from the many available options. The selection of appropriate mineral processing technique largely depends on the nature of mineralization, texture of the ore body and size of liberation of the valuable minerals (Weiss, 1985). Mineralogical assemblage gives knowledge about the nature of valuable and gangue minerals and their proportion in the ore whereas the texture refers to the crystal habits, aggregation, dissemination, mode of occurrence and form of association within the ore.

Due to high specific gravity of tungsten minerals, the ores are generally beneficiated by gravity concentration methods. However, wolframite ores may be beneficiated by high intensity magnetic separation whereas scheelite ores can be processed by froth flotation depending on their texture. For complex ores, a combination of mineral processing techniques is applied to optimize metal recovery. Since different deposits vary greatly in their characteristics, therefore different flow sheets are adopted for their beneficiation (Wills, 1992).

Tungsten deposits have been reported to occur in the Hindu Kush Range of northern Pakistan (Hildebrand et al., 2000). Zeschke (1961) first discovered tungsten as scheelite in this area during regional drainages survey using panning heavy mineral concentrate. Leak et al., (1989) of British Geological Survey in collaboration with team of Sarhad Development Authority, Peshawar, conducted a regional pan concentrate and stream sediments studies of Garam Chashma area, about $60 \mathrm{~km}$ to the north-west of Chitral City, in Khyber Pakhtoon Khawa Province and discovered scheelite mineralization on the ridge to the north of Miniki Gol. The mineralization stretches from south of Lutkoh river to north-eastwards through Miniki Gol valley and extends as far as Besti Gol, at strike length of about $20 \mathrm{~km}$ (Fig. 1). The deposit consists of a number of ore bodies. The indicated reserves of ore have been calculated to be around 1.8 million tons however; the mineable reserves are estimated to be 0.5-0.75 million tons (Anwar, 2005).

The present study is mainly focused on identification of minerals present in the ore, their relative amount, textural relationships between minerals within the ore and degree 


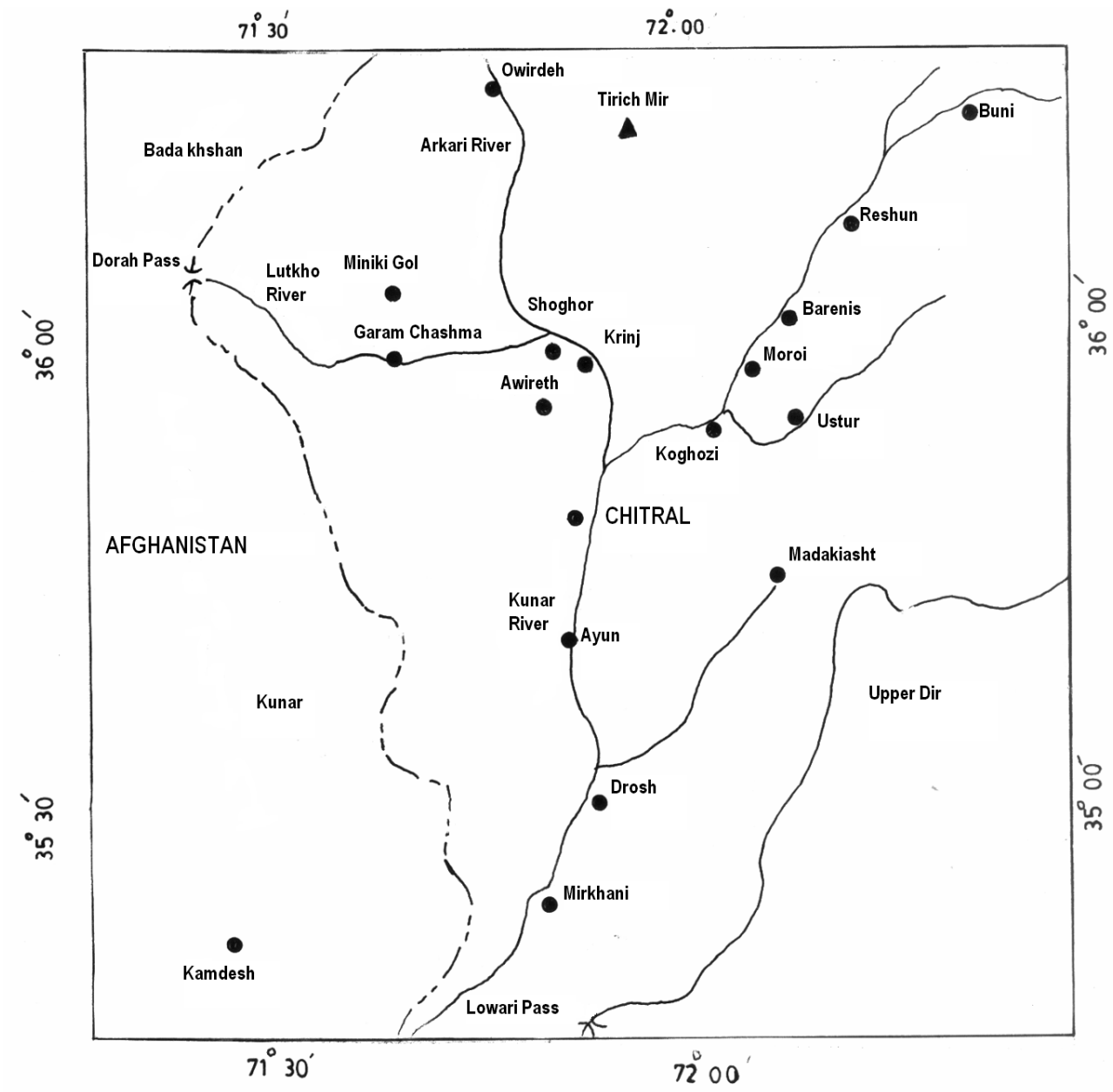

Fig. 1: Location map of Chitral tungsten ore.

of liberation of valuable mineral from associated gangue minerals. These studies are particularly useful prior to the actual selection of the process and commercial plant designing.

\section{MATERIALS AND METHODS}

\section{Sample Preparation}

Representative samples of the tungsten ore were collected from various localities of Miniki Gol and its adjoining areas such as Shish Gol, Jugh Kushu Gol, Aman Kushu Gol, and Baranazi Gol. Prospecting and evaluation work of scheelite mineralization was carried out using shortwave ultraviolet lamps during night time. The samples were obtained by excavation of trenches through drilling and blasting. The trenches were excavated in the promising zones and the specimens were collected. The samples were brought to laboratory for chemical and mineralogical investigation. The portions of these samples were also mixed to prepare a composite representative sample. The ore samples were crushed using laboratory scale jaw crusher and roll crusher. Coning-quartering and riffling techniques of sampling were applied to prepare Head sample for chemical analysis and for $\mathrm{X}$-ray Diffraction studies. These were ground to minus 200 mesh size with the help of rod mill (Denver, USA).

\section{Chemical Analysis}

Chemical analysis of the prepared sample was carried out in accordance with ASTM methods. Tungsten was determined by Spectrophotometer (Model: Spectronic-20 Bausch \& Lomb, USA). Sodium and potassium were determined by flame photometer (Model: PFP7, Jenway, England) while other constituents were estimated by atomic absorption spectrophotometer (Model: Z-8000, Hitachi, Japan). Chemical analysis of the various samples and representative sample is reported in Tables 1 and 2 respectively.

\section{X- Ray Diffractometry}

The pulverized ore sample was run on X-ray Diffractometer (Model: D-5000, Siemens, Germany). X-ray diffraction was done with a $0.02^{\circ}$ step size per second. The scan angle was ranged from $0-60^{\circ}$ and the spectrum obtained was matched with standard data. An X-ray diffractrogram of the ore is shown in Figure 2. The mineral phases identified are given in tables 3 and 4 .

\section{Petrography}

Petrography of the selected samples was carried out with polarizing microscope (Meiji, Japan). Rock chips were cut out to a thickness of about $1.0 \mathrm{~mm}$ by a diamond thin section 
Table 1: Percentage of $\mathrm{WO}_{3}$ in samples collected from different blocks of Chitral tungsten ore deposit

\begin{tabular}{|l|l|l|l|l|l|l|l|}
\hline S. \# & $\mathbf{W O}_{\mathbf{3}} \mathbf{\%}$ & $\mathbf{S . ~ \# ~}$ & $\mathbf{W O}_{\mathbf{3}} \mathbf{\%}$ & $\mathbf{S}$. \# & $\mathbf{W O}_{\mathbf{3}} \mathbf{\%}$ & $\mathbf{S . ~ \# ~}$ & $\mathbf{W O}_{\mathbf{3}} \mathbf{\%}$ \\
\hline B1-2 & 0.179 & B5-92 & 0.279 & B6-39 & 0.168 & BG-1 & 0.480 \\
\hline B1-5 & 0.135 & B5-93 & 0.081 & B6-42 & 0.517 & BG-2 & 0.460 \\
\hline B1-8 & 0.585 & B5-94 & 0.325 & B6-43 & 0.149 & BG-3 & 0.158 \\
\hline B1-11 & 0.165 & B5-95 & 0.256 & B7-45 & 0.449 & BG-4 & 0.135 \\
\hline B1-13 & 0.157 & B5-96 & 0.573 & B7-49 & 0.125 & BG-5 & 0.159 \\
\hline B1-16 & 0.225 & B5-97 & 0.721 & B8-47 & 0.091 & BG-6 & 0.182 \\
\hline B1-18 & 0.280 & B5-98 & 0.488 & B8-48 & 0.114 & BG-8 & 0.204 \\
\hline B1-19 & 0.341 & B5-99 & 0.595 & B10-89 & 0.300 & BG-9 & 0.114 \\
\hline B1-54 & 0.197 & B5-100 & 0.297 & B10-90 & 0.242 & BG-10 & 0.113 \\
\hline B1-56 & 0.516 & B5-101 & 0.314 & B10-91 & 0.106 & BG-11 & 0.078 \\
\hline B1-58 & 0.350 & B5-102 & 0.435 & B10-115 & 0.160 & & \\
\hline B1-60 & 0.198 & B5-103 & 0.139 & B10-140 & 0.465 & & \\
\hline B1-86 & 0.596 & B5-123 & 0.550 & B10-141 & 0.350 & & \\
\hline B1-87 & 0.250 & B5-126 & 0.279 & B10-142 & 0.280 & & \\
\hline B3-21 & 0.157 & B5-127 & 0.581 & B11-112 & 0.419 & & \\
\hline B3-24 & 0.113 & B5-128 & 0.418 & B12-116 & 0.495 & & \\
\hline B3-26 & 0.067 & B5-129 & 0.600 & B12-117 & 0.117 & & \\
\hline B3-29 & 0.337 & B5-130 & 0.395 & B12-121 & 0.060 & & \\
\hline B3-51 & 0.769 & B5-132 & 0.790 & B12-122 & 0.218 & & \\
\hline B3-53 & 0.222 & B5-133 & 0.395 & B12-124 & 0.215 & & \\
\hline B4-32 & 0.200 & B5-134 & 0.442 & B12-125 & 0.135 & & \\
\hline B4-34 & 0.124 & B5-137 & 0.345 & & & & \\
\hline B4-37 & 0.405 & B5-138 & 0.512 & & & & \\
\hline & & B5-139 & 0.418 & & & & \\
\hline
\end{tabular}

Table 2: Chemical composition of Chitral tungsten ore (composite sample)

\begin{tabular}{|c|c|}
\hline Constituents & Percentage \\
\hline $\mathrm{WO}_{3}$ & 0.34 \\
\hline $\mathrm{SiO}_{2}$ & 65.53 \\
\hline $\mathrm{Al}_{2} \mathrm{O}_{3}$ & 11.67 \\
\hline $\mathrm{Fe}_{2} \mathrm{O}_{3}$ & 5.65 \\
\hline $\mathrm{CaO}$ & 10.43 \\
\hline $\mathrm{MgO}$ & 0.54 \\
\hline $\mathrm{Na}_{2} \mathrm{O}$ & 0.96 \\
\hline $\mathrm{K}_{2} \mathrm{O}$ & 0.38 \\
\hline $\mathrm{LOI}$ & 3.14 \\
\hline
\end{tabular}

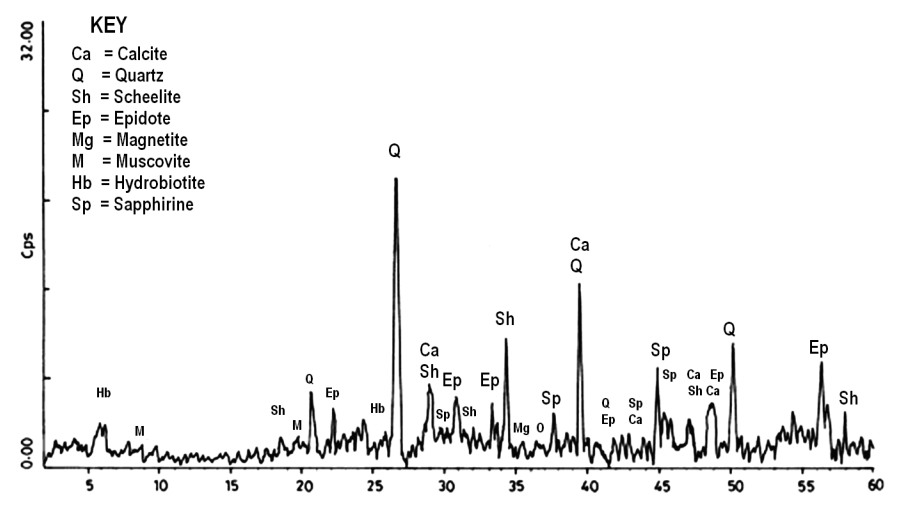

cut-off saw. These were glued to glass slide $(\sim 1$ inch by 2 inches) with one or two drops of Canada balsam and ground on a metal lap wheel utilizing progressively decreasing silicon carbide grit abrasives followed by final polishing on cloth laps using diamond pastes. After grinding down to a specified thickness of about $0.03 \mathrm{~mm}$, these were covered with cover slips and studied under microscope in transmitted light. The photomicrographs of the representative samples are presented in figures 3-12.

\section{Degree of Liberation}

The liberation of scheelite mineral was measured by grain mounts. The crushed ore was ground in a rod mill for

Fig. 2: X- Ray Diffractogram (XRD) of Chitral scheelite ore.

15 minutes and separated into a number of size fractions using different sieves. The grain mounts of various size fractions were prepared by placing a small amount of sample in one drop of glycerin on a glass slide and covering with a cover slip. These were analyzed under the microscope at a magnification of $40 \times$. The number of liberated and locked mineral grains in each sieve fraction were noted and the \%age liberation was calculated. About 100 particles were counted for each slide. The data expressing the liberation summary of the size fractions is shown in the Table 5 . 
Rashid Mehmood et al.

Table 3: Percentage of different minerals in various blocks of Chitral tungsten ore deposit

\begin{tabular}{|c|l|c|c|c|c|c|c|c|c|}
\hline $\begin{array}{c}\text { Sr. } \\
\#\end{array}$ & \multicolumn{1}{|c|}{ Minerals } & Block-1 & Block-3 \% & Block-4 & Block-5 & Block-6 & Block-7 & Block-8 & Block-10 \\
& & & & & & & & & \\
\hline 1 & & & & $\%$ & $\%$ & $\%$ & $\%$ & $\%$ & $\%$ \\
\hline 2 & Clinozoisite & 24.6 & 65.3 & 60.6 & 58.5 & 57.8 & 52.5 & 61.1 & 46.0 \\
\hline 3 & Actinolite & 10.6 & 7.8 & 7.0 & 9.7 & 4.5 & 3.5 & 8.5 & 2.0 \\
\hline 4 & Scheelite & 1.5 & 0.2 & 0.6 & 2.5 & 6.9 & 4.5 & 4.5 & 2.5 \\
\hline 5 & Calcite & 0.4 & 3.5 & 12.8 & 2.2 & 1.4 & 2.1 & 0.5 & 2.2 \\
\hline 6 & Magnetite & 1.5 & 0.5 & 0.6 & 1.7 & 0.8 & 2.3 & 0.7 & 6.5 \\
\hline 7 & Limonite & 0.2 & 0.6 & 0.2 & 0.4 & 0.5 & 0.4 & 0.3 & - \\
\hline 8 & Biotite & - & - & - & - & 2.5 & 1.5 & - & 6.0 \\
\hline 9 & Muscovite & - & & - & - & 1.8 & 3.5 & - & 4.5 \\
\hline 10 & Sphene & - & - & - & - & - & 0.9 & - & 0.5 \\
\hline
\end{tabular}

Table 4: Mineralogical composition of Chitral tungsten ore (composite sample)

\begin{tabular}{|l|l|c|c|}
\hline Sr.\# & Minerals & \% age & Specific Gravity \\
\hline 1. & Quartz $\left(\mathrm{SiO}_{2}\right)$ & 60.5 & 2.65 \\
\hline 2. & Epidote $(\mathrm{Clinozoisite}) \mathrm{Ca}_{2} \mathrm{Al}_{3}\left(\mathrm{SiO}_{4}\right)\left(\mathrm{Si}_{2} \mathrm{O}_{7}\right)(\mathrm{O}, \mathrm{OH})$ & 24.3 & 3.3 \\
\hline 3. & Amphibole $($ Actinolite $) \mathrm{Ca}_{2} \mathrm{Mg}_{5}\left(\mathrm{Si}_{8} \mathrm{O}_{22}\right)(\mathrm{OH})$ & 5.2 & 3.2 \\
\hline 4. & Scheelite $\left(\mathrm{CaWO}_{4}\right)$ & 2.4 & 6.0 \\
\hline 5. & Calcite $\left(\mathrm{CaCO}_{3}\right)$ & 1.5 & 2.71 \\
\hline 6. & Magnetite $\left(\mathrm{Fe}_{3} \mathrm{O}_{4}\right)$ & 1.8 & 5.2 \\
\hline 7. & Limonite $\left(\mathrm{FeO}_{2}(\mathrm{OH})\right.$ & 0.5 & 4.0 \\
\hline 8. & Biotite $\mathrm{K}(\mathrm{Mg}, \mathrm{Fe})_{3}\left(\mathrm{AlSi}_{3} \mathrm{O}_{10}\right)(\mathrm{OH}, \mathrm{F})_{2}$ & 2.2 & 4.3 \\
\hline 9. & Muscovite $\mathrm{K}, \mathrm{Al}_{2}\left(\mathrm{AlSi}_{3} \mathrm{O}_{10}\right)(\mathrm{OH}, \mathrm{F})$ & 1.2 & 2.8 \\
\hline 10. & Sphene $(\mathrm{CaTiSiO}$ & & 3.53 \\
\hline
\end{tabular}

\section{RESULT AND DISCUSSION}

Chemical analysis of the different samples collected from various sites of the deposits (Table 1) shows quite variation in $\mathrm{WO}_{3}$ content of the ore. On the basis of this information, it is inferred that distribution of scheelite would vary from place to place. However, the analysis of representative sample presented in Table- 2 show that the average $\mathrm{WO}_{3}$ content in the bulk sample is $0.34 \%$. The obtained grade of ore is quite sufficient to exploit it on commercial scale to produce tungsten concentrate (Srivastava \& Pathak, 2000). Pandey et al., (2001) processed a low-grade scheelite ore $\left(0.3 \% \mathrm{WO}_{3}\right)$ into a preconcentrate assaying $13 \% \mathrm{WO}_{3}$ The pre-concentrate either can be directly utilized for extraction of tungsten (W) metal by hydrometallurgical treatment or it can be further upgraded into a high grade concentrate (Guar, 2006). It is also clear from Table 2 that the main impurity is $\mathrm{SiO}_{2}$. It is present due to quartz and to some extent other silicate minerals as is obvious from Table-3. After $\mathrm{SiO}_{2}$ the other major impurity is iron which is present in the form of magnetite. $\mathrm{CaO}$ is a part of calcite and scheelite where $\mathrm{Al}_{2} \mathrm{O}_{3}, \mathrm{Na}_{2} \mathrm{O}$ and $\mathrm{K}_{2} \mathrm{O}$ are mainly associated with silicate minerals.

The X-ray diffraction analysis (Fig. 2) confirms the presence of considerable amount of scheelite mineral. It was identified by JCP.CAT search/match programme of the $\mathrm{X}$-ray Diffractometer that the other peaks corresponds to gangue minerals which mostly comprised of calcite, epidote (clinozoisite), amphibole (actinolite), magnetite, biotite, muscovite, sphene and predominant quantities of quartz.

The microscopic examination of thin sections of the ore samples show that scheelite looks off-white to yellow in colour with greasy luster in plane polarized light (PPL) and grayish white to yellowish brown in cross polarized light (XPL). It has massive and granular shape crystals which occur as medium to fine grains embedded in quartz grains (Figs. 3-5). Under the microscope, the grain size of scheelite shows wide variations. It ranges from coarse crystals of $0.2 \mathrm{~mm}$ to fine disseminated particles of $0.03 \mathrm{~mm}$. However, the majority of grains have a size in the range of 0.08 to $0.12 \mathrm{~mm}$. The grain habits range from anhedral to euhedral tetragonal crystals with highly lustrous gray faces and a moderately high birefringence of 0.016 under crossed Nichols.

The quartz is present as medium to coarse grained matrix mineral ( 0.5 to $2.0 \mathrm{~mm}$ ). Quartz appears as white when viewed under plane polarized light and has some shade of gray 
Table 5: Mesh of liberation of scheelite mineral in Chitral tungsten ore

\begin{tabular}{|c|c|c|c|c|}
\hline $\begin{array}{c}\text { Size Fraction } \\
\text { (ASTM) }\end{array}$ & $\begin{array}{c}\text { Free Scheelite Grains } \\
\mathbf{( \% )}\end{array}$ & $\begin{array}{c}\text { Locked Scheelite Grains } \\
\mathbf{( \% )}\end{array}$ & $\begin{array}{c}\text { Free Gangue } \\
\text { Grains (\%) }\end{array}$ & $\begin{array}{c}\text { Scheelite } \\
\text { Liberation (\%) }\end{array}$ \\
\hline$-50+70$ & 3.63 & 8.39 & 87.98 & 32.20 \\
\hline$-70+100$ & 4.67 & 4.38 & 90.95 & 51.57 \\
\hline$-100+150$ & 4.93 & 2.20 & 92.77 & 69.10 \\
\hline$-150+200$ & 5.56 & 1.01 & 93.43 & 84.63 \\
\hline$-200+250$ & 5.61 & 0.37 & 94.02 & 93.81 \\
\hline$-250+300$ & 5.65 & 0.25 & 94.10 & 95.78 \\
\hline-300 & 5.66 & 0.18 & 94.36 & 96.87 \\
\hline
\end{tabular}

(typical grayish) when viewed under crossed polarizer (Figs. 3-5). Magnetite grains are also coarse to medium, subhedral to anhedral and observed as gray with brownish tint in plane polarized light and dark black when viewed under crossed polarizer. It has no birefringence. Magnetite is partially altered to limonite (white blue) on exposed surface (Figs. 6-7). Calcite is present as anhedral colorless grains. It is almost indistinguishable from other minerals under plane polarized light because of the distorted surface of the crystal, combined with its high birefringence and interference order.

Biotite looks as dark brown in plane polarized light and brown to dark red in cross polarizer (Figs. 8-9). It is almost opaque. Muscovite is colorless with good cleavage. Epidote, mostly clinozoisite, is identified by its light-gray coloration in plane polarized light. Under cross polarizer, it is the light-bluish

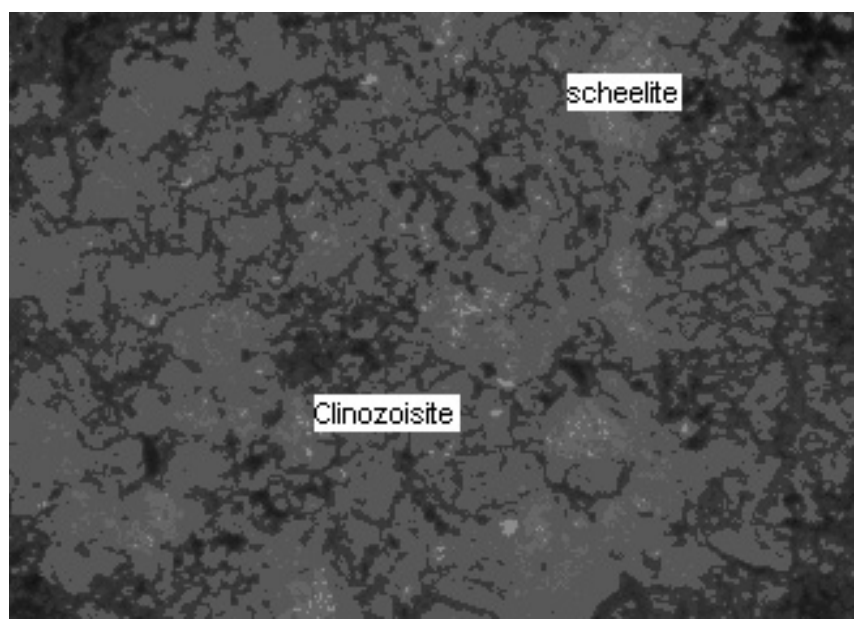

Fig. 3 : Off-white to yellowish brown (angular to sub-rounded) grains of scheelite embedded in quartz and clinozoisite grains in plane polarized light $(\mathrm{PPL})(40 \times)$.

gray mineral. Photomicrographs of epidote (clinozoisite) in plain polarized light and in crossed polar are shown in figures 9-10. Actinolite appears colourless under plane and cross polarized light (Figs. 11-12).

Prospecting studies of samples collected from trenches and exposures show that scheelite mineralization mainly occurs in a calc-silicate quartzite rocks at Miniki Gol and adjoining areas. Two scheelite bearing calc-silicate quartzite units have been identified here. The most prominent horizon is fine-grained calc-silicate quartzite with maximum thickness of $4.5 \mathrm{~m}$. The second horizon varies between $0.4 \mathrm{~m}$ to $1.0 \mathrm{~m}$ and is composed of medium-grained quartzite. Scheelites hosting quartzitic horizons are found within quartz mica schists. Quartzites are well developed in the upper reaches where as quartz mica schist is prominent at lower horizons. In addition to calc-silicate, some mineralization has also been found to occur in carbonate member of rock in Besti Gol samples. Sang Last is the only scheelite prospective area near by DamDam Mountains in Besti Gol. The major ore body at Besti Gol is hosted by the granular limestone. According to Leake et al., (1961) scheelite mineralization occurs predominantly

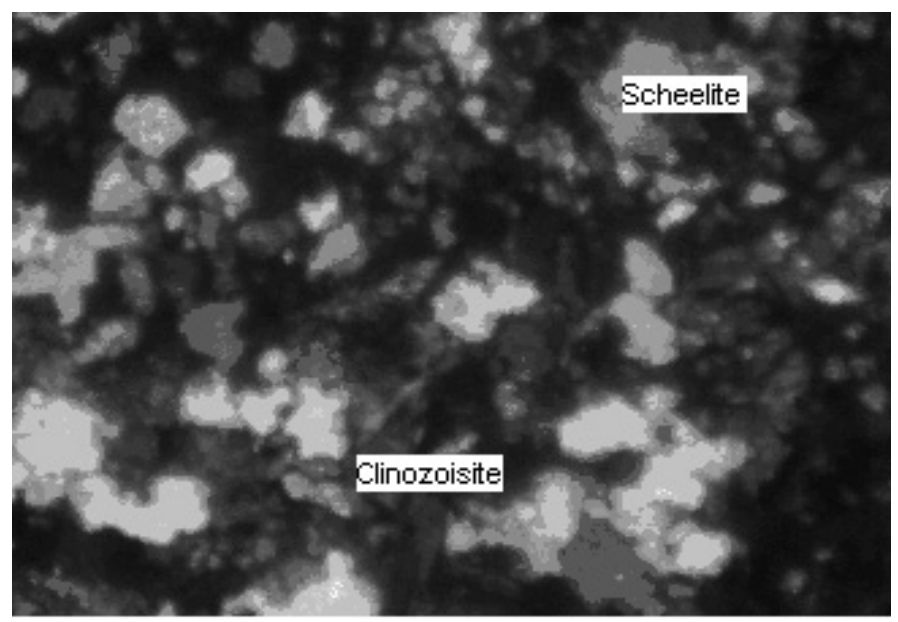

Fig. 4: Same photomicrograph under cross polarized light (XPL) $(40 \times)$ showing yellowish to light brown crystals of scheelite in gray quartz and light bluish clinozoisite matrix.

in clinozoisite-bearing calc-silicate quartzite beds within a sequence of mica schist and subordinate graphitic phyllite, mica quartzite, tourmalinite and feldspathic gneiss as strata bound deposits. But in our studies it has been found that in addition to quartzite, some scheelite is also hosted in limestone at Besti Gol area. 


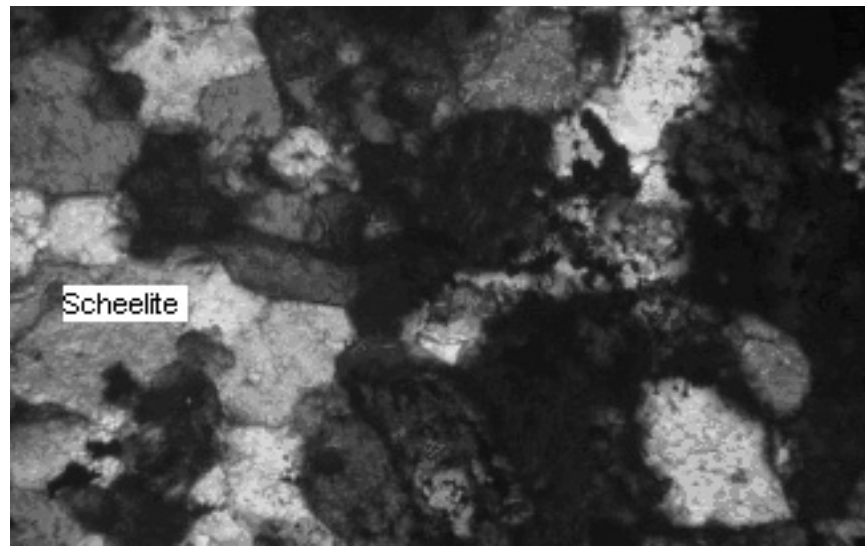

Fig. 5: Another view under high magnification $(80 \times)$ shows grayish white to yellowish brown scheelite crystals in XPL.

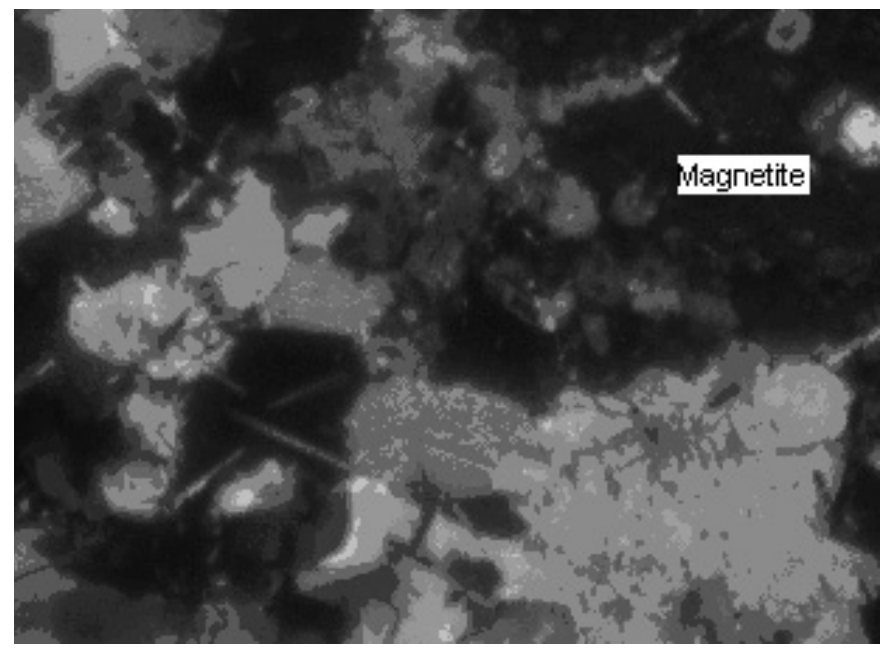

Fig. 7: Magnetite grains observed dark black under XPL in same photomicrograph $(80 \times)$.

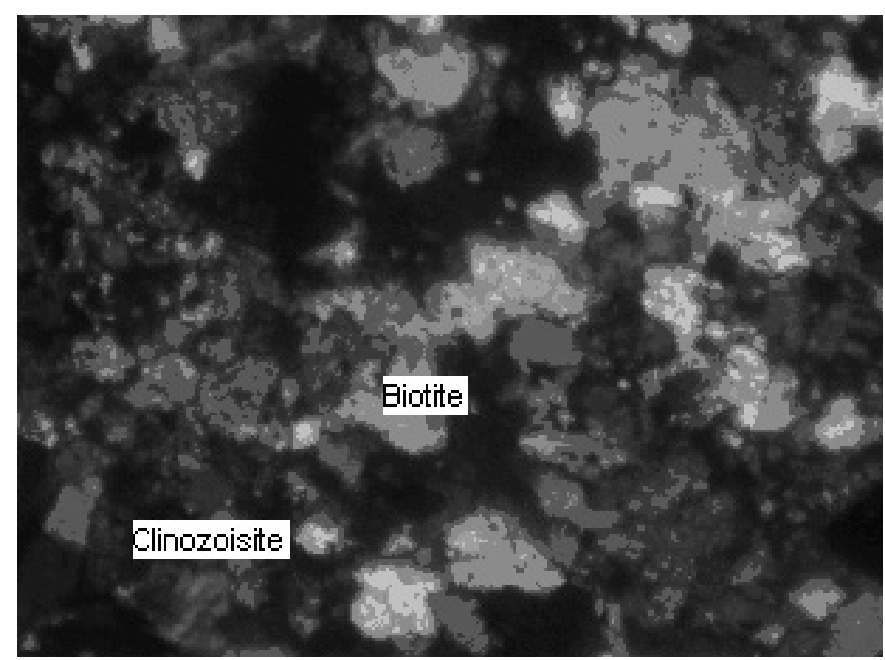

Fig. 9: Dark brown grains of biotite and bluish gray clinozoisite having different orientations in XPL $(40 \times)$.

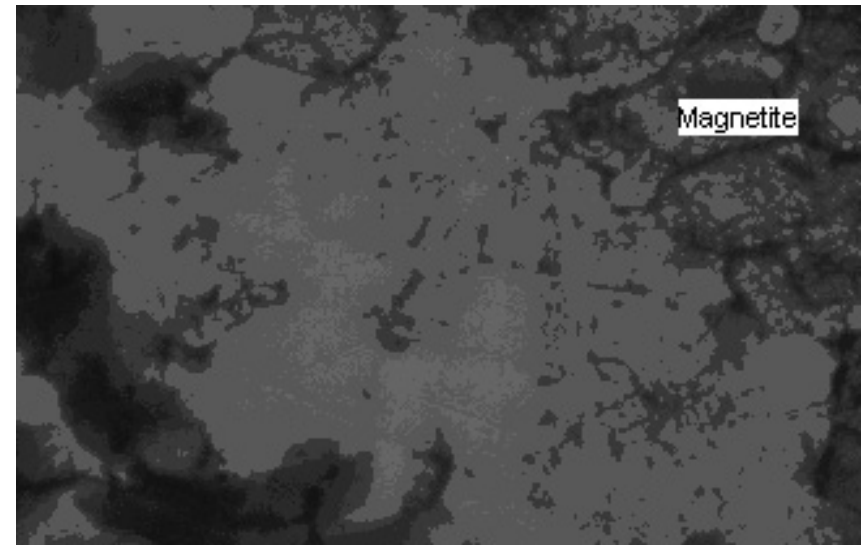

Fig. 6: Magnetite grains looks gray with brownish tint in PPL $(\mathbf{8 0} \times)$.

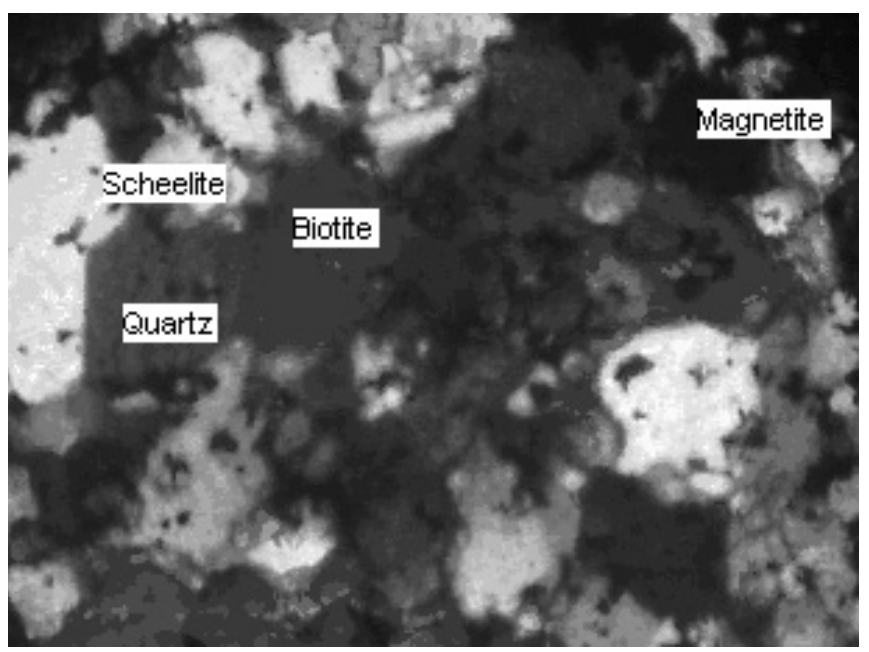

Fig. 8: An intermixing of off-white (medium to fine grained) scheelite, gray quartz, bluish clinozoisite, dark red biotite and black magnetite in XPL $(80 \times)$.

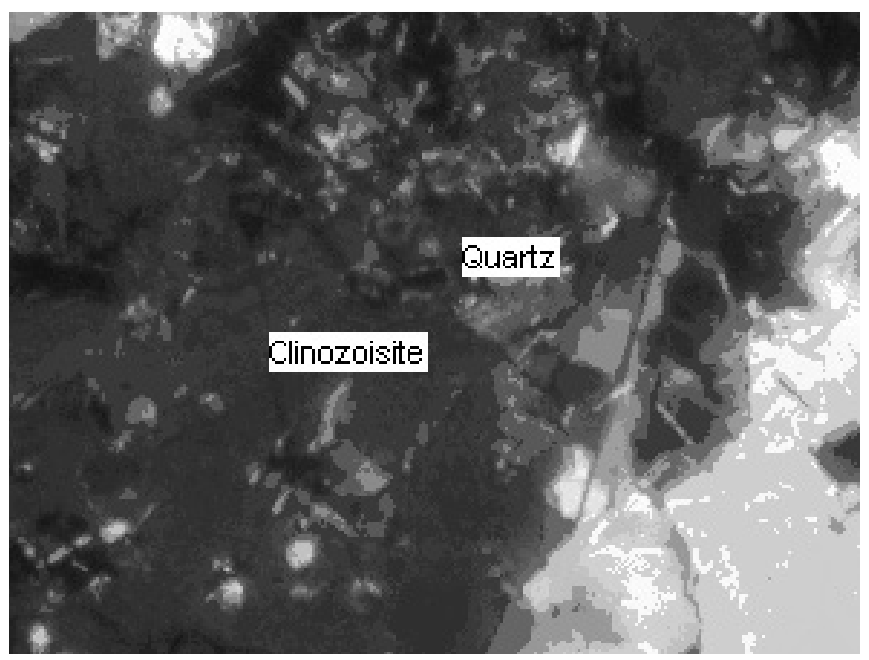

Fig. 10: The clinozoisite (light-bluish gray) associated with gray quartz in XPL $(\times 40)$. 
For efficient ore beneficiation, the knowledge of predominant range of grain (crystal) size is an important factor. It helps to take decisions concerning the grind size to which the ore should be ground in order to liberate the valuable mineral. Although, the grain size affects the recovery of any valuable element, but it is particularly important when dealing with precious and rare metals, whose full recoveries are normally required (Ferrara et al., 1989). Grinding of the ore is the most energy consuming unit operation in ore processing. Grinding at the coarse size, not only save the energy but also helps to reduce the production of slimes. The slimes generated not only decreases the recovery but also hinder in achieving the desired grade. Therefore, ore is ground to a size at which maximum minerals grains are liberated at the coarsest possible size, avoiding over-grinding (King, 1994).

The degree of liberation of economic minerals in new ores is often determined to estimate the required grind size (Ferrara et al., 1989). Table 5 presents the degree of liberation of scheelite mineral in various size fractions. It is clear from this Table that liberation increases with a reduction in particle

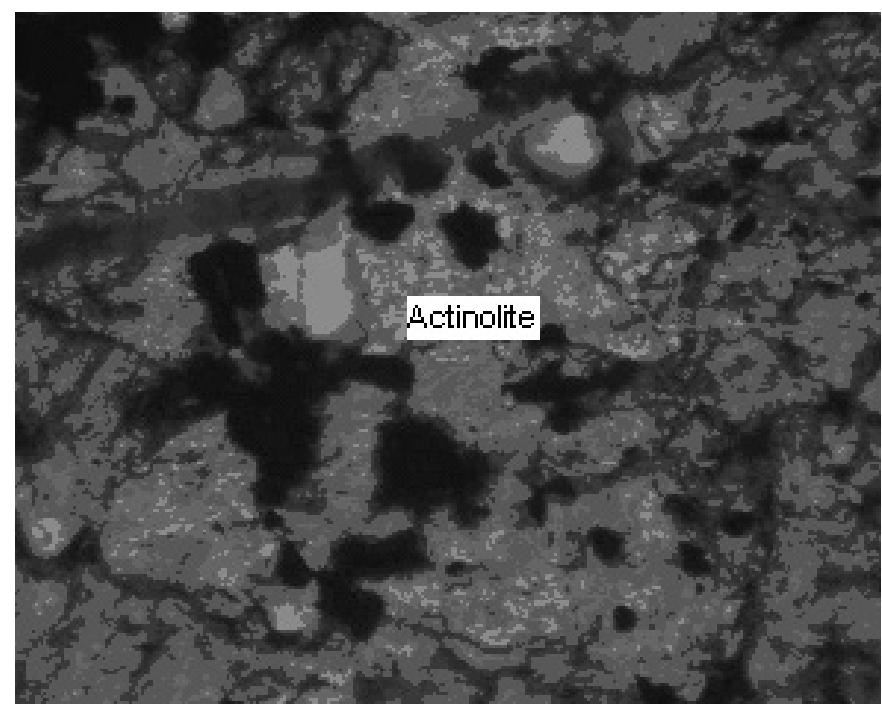

Fig. 11: The photomicrograph shows actinolite grain (colourless) in PPL (40×).

size and about $94 \%$ scheelite grains are liberated when the ore is ground to minus 200 mesh $(74 \mu \mathrm{m})$. Practically, ore is grind to a size where the economic factor of the process is maximized and particle size is never reduced to achieve $100 \%$ liberation (King, 1994). Therefore, in order to have a sufficient proportion of liberated scheelite grains with minimum level of locked particles, this ore should be ground from 80 to $90 \%$ minus 200 mesh size. As mentioned earlier, the average grain size of scheelite also falls in this range.

Tungsten minerals are very amenable to gravity concentration because of their high specific gravity (Rao, 1996). In present ore, scheelite has specific gravity from 5.9 to 6.1 and associated gangue minerals have specific gravity ranging from 2.6 to 4.0 except magnetite. Due to this significant difference in specific gravity, it is possible to upgrade this ore by gravity concentration technique which can reduce most of the undesirable minerals. Magnetite having specific gravity (5.0 to 5.5) close to scheelite may be recovered along with scheelite concentrate. But, it is possible to separate it from concentrate by magnetic separation because of its high susceptibility.

The amenability of ores to beneficiation depends not only on nature of minerals but also on their texture (Adams, 1986). The ore under investigation is fine-grained in texture and some of scheelite crystals are finely disseminated within the host quartzite. Liberation of such fine scheelite grains (30$50 \mu \mathrm{m})$ from the associated gangue minerals requires sufficient grinding. Since scheelite tends to slime badly on excessive grinding due to its brittle and friable nature. Therefore, gravity concentration techniques may not succeed to produce desired grade concentrate with high recovery.

However, to produce economic grade tungsten concentrate with acceptable recovery, such ore can be treated either by a combination of physical beneficiation techniques such as gravity concentration at coarser size followed by re-

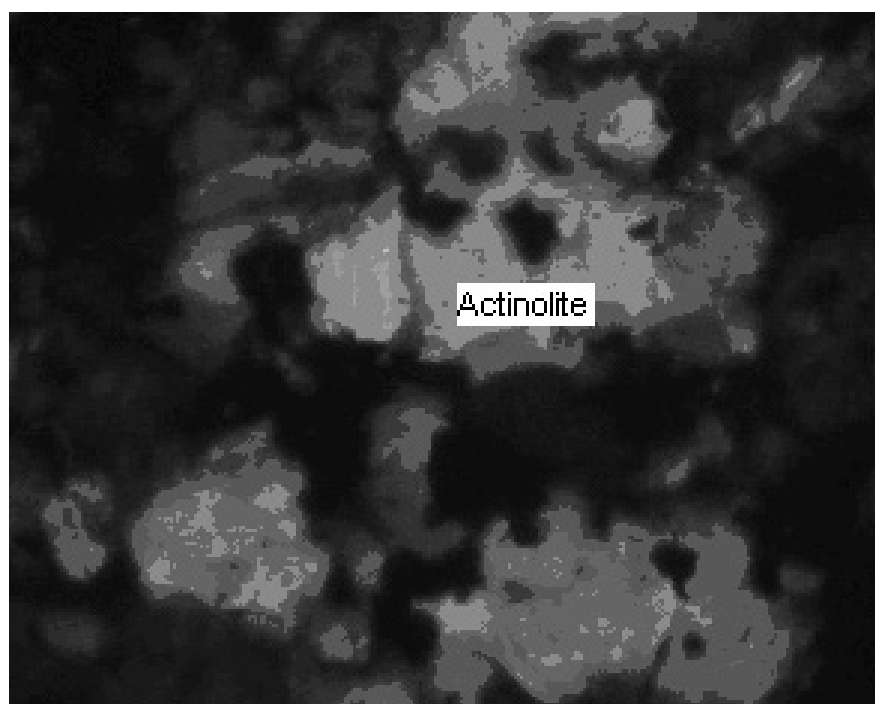

Fig. 12: The actinolite grains (colourless) in same photomicrograph under XPL $(40 \times)$.

grinding of the pre-concentrate and subsequently its flotation or by an all over froth flotation process. Flotation is an important process in mineral processing which utilize the physical and chemical properties of different minerals for their separation. The scheelite mineral $\left(\mathrm{CaWO}_{4}\right)$ generally responds well to flotation process using carboxyl acid collector (Wills, 1992). The mineralogical composition of the ore indicates that only calcite $\left(\mathrm{CaCO}_{3}\right)$ may interfere in its flotation because of similar surface behaviour. Therefore, this ore can be beneficiated by single froth flotation process. The associated gangue minerals such as quartz and various silicate minerals can be depressed using sodium silicate or sodium pyrophosphate as depressant while the carbonate gangue mineral (calcite) may be depressed either with quebracho or tannins. 


\section{CONCLUSSIONS}

It is concluded that the only valuable tungsten bearing mineral identified in the samples collected from various localities of Miniki Gold deposit is scheelite while the rest of the matter is associated gangue minerals. The ore body comprises of mainly quartz and clinozoisite as major minerals while actinolite, magnetite, calcite, biotite, muscovite and sphene are minor minerals. Thin sections of the ore reveal that it is fine-grained in texture and minerals phases are finely disseminated in host quartz. The distribution of free and locked scheelite grains of various size fractions of the ore shows that it should be ground to more than $80 \%$ minus 200 mesh size to have an economic degree of liberation. Mineralogical and textural observations of the ore indicate that the froth flotation is more suitable technique for its up-gradation as compared to gravity concentration methods.

\section{ACKNOWLEDGEMENTS}

The authors are highly grateful to National Development Complex (NDC) for providing facilities for exploration and prospecting of tungsten ore. The authors are also thankful to Dr. Muhammad Nawaz, Institute of Geology, University of the Punjab, for his valuable co-operation in ore microscopy.

\section{REFERENCES}

Adams, R.W., 1986, Mining Chemical Handbook. American Cyanamid Company, NJ, USA, pp. 112

Anwar, M. S., 2005, Mineral Potentials of Pakistan and Role of PCSIR. In: Roonwal GS, editor. Mineral Resources and Development. Delhi, India: Daya Publishing House, pp. 36-43.

Blackburn, W.H., 1988, Principles of Mineralogy. Iowa, USA: W.C. Browns Publishers. pp. 247-248,

Chaudhary, S. 2007, Mineralogy, petrochemistry and genesis of scheelite-bearing skarns and related acid magmatism at Sargipali, Eastern India. Jour. Nep. Geol. Soc. V. 36, pp. 1-8.

Ferrara, G. Preti U, Meloy TP 1989, Inclusion shape, mineral texture and liberation. Int. J. Miner. Process. V. 27, pp. 295-308.
Foster, R. J., 1988, General Geology. Merrill Publishing Company, Columbus, Ohio, USA, $5^{\text {th }}$ Ed. pp. 18 .

Guar, R.P.S., 2006, Modern hydrometallurgical production methods for tungsten. JOM v.58, pp. 45-49.

Hildebrand, P. R., Searle M.P, Shakirullah, Khan Z, Van Heijst H.J. 2000,. Geological evolution of the Hindu Kush, NW Frontier Pakistan: active margin to continent-continent collision zone. Geol. Soc., London, Special Publications, v.170, pp. 277-293.

King, R. P., 1994, Comminution and liberation of minerals. Miner. Eng. V.7, pp. 129-140.

Leake, R.C., Fletcher C.J.N. Haslam H.W, Khan B, Shakirullah 1989, Origin and Tectonic Setting of Strata Bound Tungsten Mineralization within the Hindu Kush of Pakistan. J. Geol. Soc. V.146, pp. 1003-1016.

Pandey, B.D., Kumar V, Bagchi D, Jana R.K, Premchand 2001, Processing of tungsten pre-concentrate from low-grade ore to recover metallic values. Process. Extr. Metall. Rev. V.22, pp. 101-120.

Rao, N.K., 1996, Beneficiation of tungsten ores in India: A review. Bull. Mater. Sci. v.19, pp. 201-265.

Srivastava, J.P, Pathak P.N 2000, Pre-concentration: a necessary step for upgrading tungsten ore. Int. J. Miner. Process. V. 60, pp. 1-8.

Tornos, F. Galindo C, Crespo J.L, Spiro B.F 2008,. Geochemistry and Origin of calcic tungsten-bearing skarns, Los Santos, Central Iberian Zone, Spain. Can. Mineral. V.46, pp. 87-109.

Weiss, N.L., 1985, SME Mineral Processing Hand Book. New York, USA: Society of Mining Engineers (SME). New York, USA, Vol. 2, Section 27, 18p.

Wills, B.A., 1992, Mineral Processing Technology. 5th Ed. Pergamon Press, New York, USA, 464p.

Zeschke, G. 1961, prospects for ore deposits by panning heavy minerals from river sands. Econ. Geol. V.56, pp. 12501257.

Zulfiqar, A. Hariri M.M., 2006, Formation and mineral chemistry of a calcic skarn from Al-Madhiq, SW Saudi Arabia. Geochem. V. 66, pp. 187-201. 